\title{
STOSOWANIE NIEFARMAKOLOGICZNYCH METOD LECZENIA W NAJCZESTSZYYCH PROBLEMACH ZDROWOTNYCH U DZIECI
}

\section{NON-PHARMACOLOGICAL TREATMENT APPLIED IN THE MOST COMMON HEALTH PROBLEMS IN CHILDREN}

\author{
Jolanta Witanowska ${ }^{1, \text { a }}$, Urszula Nowak ${ }^{1, b}$, Beata Jarecka ${ }^{2, \mathrm{c}}$, Angelika Pastuszka1, \\ Jędrzej Kamyk ${ }^{1}$ \\ ${ }^{1}$ Zakład Pielęgniarstwa Pediatrycznego Katedry Pediatrii, Wydział Nauk o Zdrowiu w Katowicach, Śląski Uniwersytet Medyczny w Katowicach \\ ${ }^{2}$ Oddział Kliniczny Pediatrii Katedry Pediatrii, Wydział Nauk o Zdrowiu w Katowicach, Śląski Uniwersytet Medyczny w Katowicach
}

${ }^{\text {a }}$ https://orcid.org/0000-0002-5547-214X

${ }^{\mathrm{b}}$ https://orcid.org/0000-0001-9254-1354

${ }^{c}$ https://orcid.org/0000-0002-0232-7766

DOI: https://doi.org/10.20883/pielpol.2021.16

\section{STRESZCZENIE}

Wstęp. Historia lecznictwa ludowego sięga czasów starożytnych. Wiedza zdobyta na temat leczenia przekazywana była z pokolenia na pokolenie.

Cel. Celem badań była analiza wiedzy rodziców/opiekunów w zakresie alternatywnych metod postępowania wobec chorego dziecka.

Materiał i metoda. Badania przeprowadzono w dwóch grupach. W badaniu łącznie wzięły udział 132 osoby. Materiał badawczy zebrano przy użyciu anonimowej ankiety.

Wyniki. Analizie poddano materiał dotyczący najczęściej stosowanych naturalnych sposobów postępowania wobec dzieci z wybranymi problemami zdrowotnymi, takimi jak: biegunka, przeziębienie, gorączka i oparzenia.

Wnioski. 1) W badanych grupach ok. $80 \%$ osób stosuje wobec chorych dzieci niefarmakologiczne metody postępowania. 2) Najczęściej opiekunowie stosują preparaty ziołowe i czynnik fizykalne. 3) W obu badanych grupach podejmowane działania niefarmakologiczne wobec chorych dzieci były podobne. 4) Jako źródło informacji w badanym zakresie opiekunowie wskazywali Internet i znajomych.

SŁOWA KLUCZOWE: medycyna niekonwencjonalna, dzieci, problemy zdrowotne.

\section{Wstęp}

Od początku istnienia człowiek, aby przetrwać, musiał dbać o to, co było dla niego najważniejsze-zdrowie. Gdy chorował, szukał pomocy w otoczeniu, czyli w przyrodzie, w zachowaniu zwierząt, właściwościach roślin i minerałów [1]. Przyczyny chorób upatrywane były w niekorzystnym oddziaływaniu na zdrowie kosmosu, magii, natury i demonów. Wiedza zdobyta na temat leczenia przekazywana była z pokolenia na pokolenie [2]. Wów-

\begin{abstract}
Introduction. The history of folk healing dates back to ancient times. The knowledge gained about the treatment was passed down from generation to generation.

Aim. The aim of the study was to analyse the knowledge of parents/caregivers regarding alternative methods of dealing with a sick child.

Material and Method. The study was conducted in two groups. A total of 132 people participated in the study. The research material was collected using an anonymous questionnaire.

Results. The material concerning the knowledge of natural ways of dealing with children with selected health problems such as diarrhoea, cold, fever and burns was analysed.

Conclusions. 1) In the study groups, about $80 \%$ of people use non-pharmacological methods of management for sick children. 2) Most often, caregivers use herbal preparations and physical agents. 3) The non-pharmacological effects on sick children were similar in both study groups. 4) Caregivers pointed to the Internet and friends as sources of information in the study area.
\end{abstract}

KEYWORDS: unconventional medicine, children, health problems.

czas wyłonili się w społeczeństwach znawcy, specjaliści, szamani, którzy posiedli wiedzę i postanowili walczyć z chorobą i śmiercią. Na przełomie XIX i XX wieku specjalistami w dziedzinie medycyny wśród ludności wiejskiej byli zielarze, guślarze, zażegnywacze, baby, wróże, których darzono społecznym zaufaniem i powierzano im opiekę nad zdrowiem. Praktyki ich zgodne były z wierzeniami i tradycją ludową, uwzględniały kul- 
turę ludności wiejskiej, a ponadto praktycy byli zawsze osiągalni [2].

\section{Cel}

Celem badań było zestawienie najczęściej stosowanych przez badanych alternatywnych metod postępowania wobec dziecka z wybranymi problemami zdrowotnymi. Po analizie zebranego materiału badawczego planuje się uzyskać odpowiedź na następujące problemy badawcze:

- W jakich problemach zdrowotnych u dzieci opiekunowie najczęściej stosują działania niefarmakologiczne?

- Jakie najczęściej działania niefarmakologiczne są przez badanych podejmowane?

- $\quad$ Czy w badanych grupach stosowano podobne postępowanie niefarmakologiczne?

- $\quad$ Z jakich źródeł informacji korzystali badani?

\section{Materiał i metoda}

Osoby badane podzielono na dwie grupy ze względu na miejsce badania, aby sprawdzić, czy najczęściej stosowane sposoby postępowania były podobne.

W badaniu łącznie wzięły udział 132 osoby. Materiał badawczy zebrano przy użyciu autorskiego kwestionariusza ankiety, który zawierał pytanie charakteryzujące badaną grupę oraz pytania z zakresu najczęściej stosowanych metod.

Analizy uzyskanego materiału dokonano przy użyciu arkusza kalkulacyjnego MS Office Excel. Wyniki przedstawiono w postaci wykresów, a opis zmiennych obejmował liczbę $\mathrm{n}$ i procent odpowiedzi.

Grupę I $(n=80)$ stanowili rodzice dzieci uczęszczających do Przedszkola nr 1 oraz rodzice dzieci - pacjentów NZOZ na terenie Wodzisławia Śląskiego. Kobiety w tej grupie stanowiły $88 \%$, a mężczyźni $12 \%$ badanych. Aż 65\% respondentów posiadało wykształcenie średnie, $30 \%$ wyższe, a tylko $5 \%$ badanych - zawodowe. Ponad połowa (65\%) badanych to osoby w wieku od 18-30 lat, $25 \%$ stanowią osoby w wieku od 31-40 lat. Pozostałe $10 \%$ to osoby w przedziale wiekowym od $41-50$ lat.

Grupe II stanowiły 52 osoby, byli to rodzice dzieci hospitalizowanych w Szpitalu Specjalistycznym Nr 2 w Bytomiu. W badanej grupie było $73 \%$ kobiet oraz 27\% mężczyzn. Spośród wszystkich badanych osób najliczniejszą grupę - 37\% - stanowili badani z grupy wiekowej od 21 do 30 lat. Nieco mniej 35\% stanowiły osoby w wieku od 31 do 40 lat, 15\% było w wieku od 41 do 50 lat. Najmniej liczną grupą wśród badanych byli rodzice do 20 roku życia (4\%). W badanej grupie 38\% osób miało wykształcenie zawodowe, 37\% wykształcenie średnie. Wśród badanych rodziców, wykształcenie wyższe posiadało 19\%, 4\% osób miało wykształcenie podstawowe, a $2 \%$ badanych przyznało brak jakiegokolwiek wykształcenia.

\section{Wyniki}

W grupie I jako najbardziej znane metody działań niefarmakologicznych badani wymieniali akupunkturę i akupresure - 94\% ( $n=75)$, fitoterapię - 84\% ( $n=67)$, homeopatię $-69 \%(n=55)$, aromaterapię $-79 \%(n=63)$ i kręgarstwo - 69\% ( $n=55)$.

Do najmniej znanych metod należała argilloterapia $3 \%(n=2)$ oraz arteterapia i muzykoterapia.

Natomiast w II grupie 81\% ( $n=42)$ respondentów wymieniało diety, $75 \%(n=39)$ masaże, 62\% ( $n=32$ ) nawodnienie, 58\% ( $n=30$ ) kąpiele lecznicze. $Z$ kolei $52 \%$ ( $n=27)$ znało nacierania i aromaterapie, 48\% ( $n=25)$ napary, 33\% ( $n=17)$ akupresure, 29\% $(n=15)$ płukanki, 21\% ( $n=11)$ fitoterapię oraz apiterapię, 13\% $(n=7)$ irydologię. Najmniej znanymi metodami w tej grupie okazały się chromoterapia $6 \%(n=3)$ oraz litoterapia, sylwoterapia oraz ortopatia po $4 \%(n=2)$.
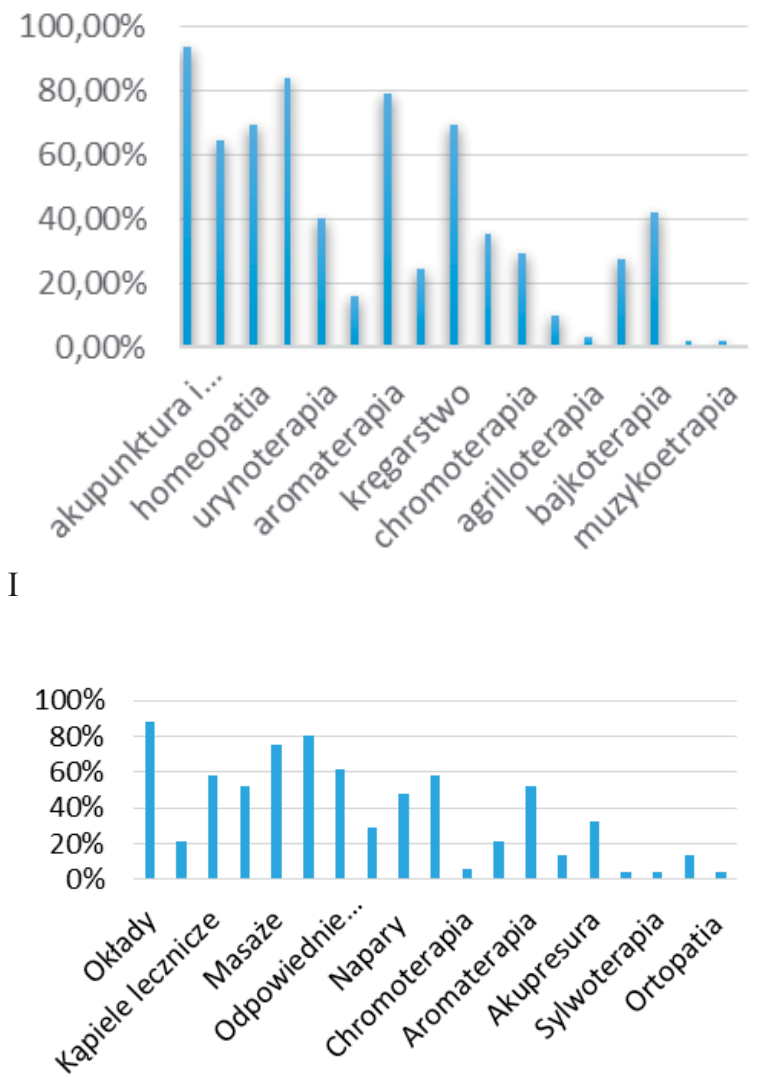

II

Rycina 1. Zestawienie najbardziej znanych metod postępowania w badanych grupach

Figure 1. Summary of the best-known management methods in the studied groups

Źródło: opracowanie własne

Source: own study 
Poddano także analizie najczęstsze sposoby pomocy dziecku z biegunką.

I grupa badanych najczęściej stosowała dietę - 93\% ( $n=74)$. W II grupie większość badanych stosowała nawodnienie $-83 \%(n=43), 37 \%(n=19)$ specjalną dietę, $21 \%(n=11)$ leki, $17 \%(n=9)$ herbaty ziołowe oraz $4 \%$ ( $\mathrm{n}=2$ ) napary ziołowe (Rycina 2).

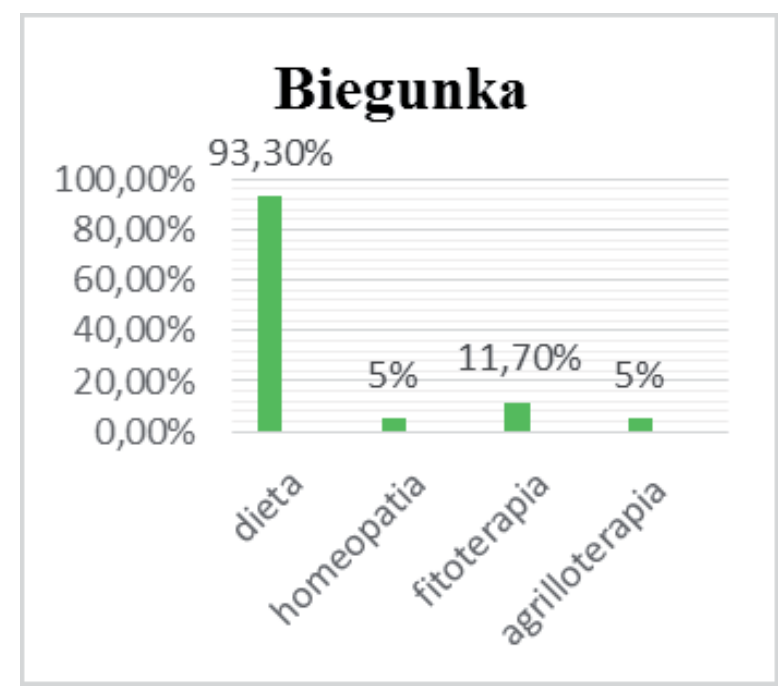

I

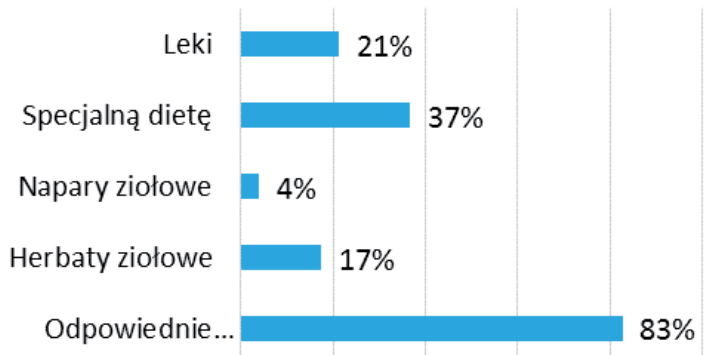

$\begin{array}{llllll}0 \% & 20 \% & 40 \% & 60 \% & 80 \% & 100 \%\end{array}$

II

Rycina 2. Zestawienie najczęściej stosowanych metod postępowania w badanych grupach u dziecka z biegunką

Figure 2. List of the most frequently applied methods of management in the studied groups in a child with diarrhea

Źródło: opracowanie własne

Source: own study

Kolejnym zaburzeniem poddanym analizie było przeziębienie. W grupie I najczęściej wybieranym sposobem postępowania była fitoterapia 68\% ( $n=54)$, a w II grupie herbatki ziołowe $(n=34)$, czyli również stosowanie preparatów ziołowych (Rycina 3).

Następnym elementem poddanym analizie było postępowanie badanych z dzieckiem gorączkującym. W I grupie badani stosowali herbatki ziołowe 95\% ( $n=76)$, wywary $39 \%$ ( $n=31)$, czosnek, cytrynę $2 \%(n=2)$, zimne okłady, chłodne kąpiele 95\% ( $n=76)$, homeopatię 5\% $(n=4)$.
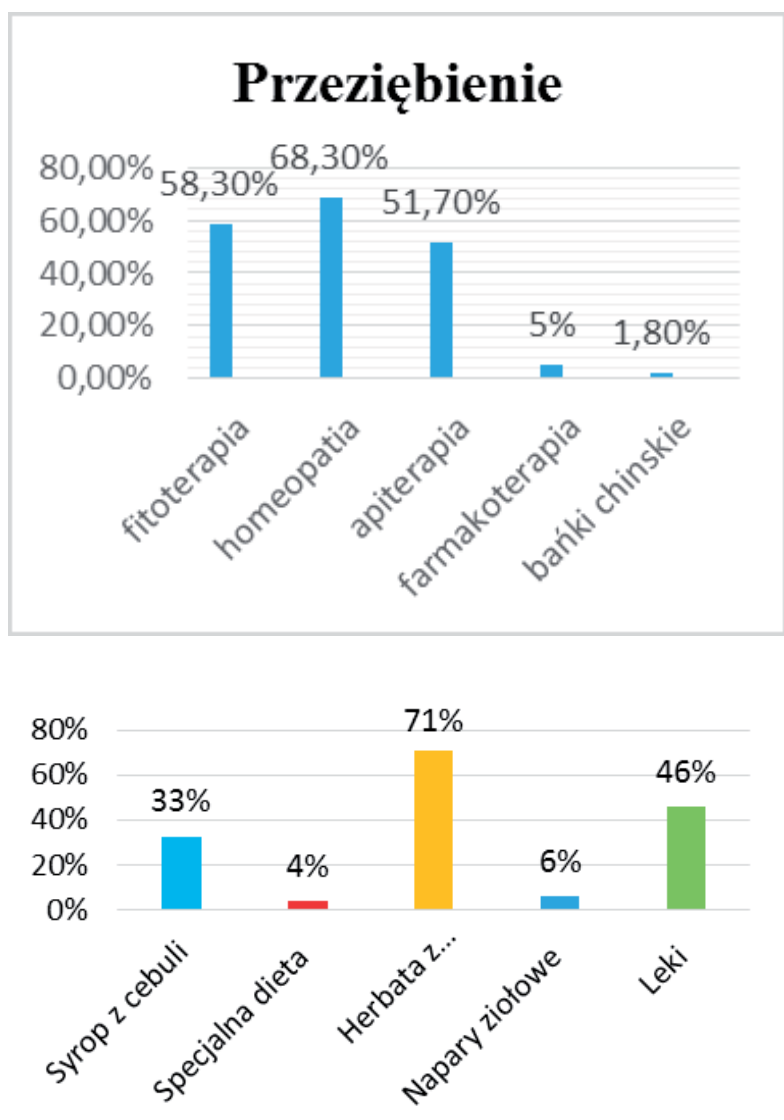

Rycina 3. Zestawienie najczęściej stosowanych metod postępowania w badanych grupach u dziecka przeziębionego

Figure 3. List of the most frequently applied methods of management in the studied groups in a child with a cold

Źródło: opracowanie własne

Source: own study

II grupa badanych w przypadku wystąpienia gorączki u dziecka stosowała w 79\% ( $n=41)$ zimne okłady i kąpiel ochładzającą, 65\% ( $n=34)$ stosowało leki, 25\% $(n=13)$ odpowiednią temperaturę otoczenia, $23 \%(n=12)$ luźne ubrania, a chłodne napoje $8 \%(n=4)$ (Rycina 4).

W przypadku oparzeń badani w I grupie uznali, że środkami niekonwencjonalnymi można leczyć również lekkie oparzenia i wymieniali apiterapię 7\% $(n=6)$, sokoterapię poprawiającą gojenie się ran $25 \%(n=20)$, środki domowe na oparzenia: aloes, jogurt, ogórek, ziemniak $76 \%$ ( $n=61)$. W II grupie stosowano najczęściej $62 \%(n=32)$ zimną wodę, $58 \%(n=30)$ zimne okłady, $40 \%$ ( $n=21)$ maści, 25\% ( $n=13$ ) leki przeciwbólowe, a $8 \%(n=4)$ okłady z różnych części roślin leczniczych.

Jako źródła wiedzy badani wskazywali w I grupie na Internet 52\% ( $n=42)$, książki 35\% ( $n=28)$, telewizję 15\% ( $n=12)$, znajomych i rodzinę $47 \%(n=38)$. Natomiast w II grupie najczęściej jako źródło wiedzy badani wymieniali członków rodziny lub znajomych 81\% ( $n=42)$, w następnej kolejności Internet 50\% ( $n=26)$, książki i artykuły w czasopismach 25\% ( $n=13)$, telewizję 15\% $(n=8)$. 


\section{Dyskusja}

W obecnych czasach wydaje się, że medycyna alternatywna, niekonwencjonalna w obliczu ogromnego rozwoju medycyny naukowej odchodzi w zapomnienie. Tak jednak nie jest, przeciwnie następuje coraz częściej zwrot w kierunku niefarmakologicznych sposobów postępowania [3].

Do najczęściej stosowanych metod postępowania należą:

- $\quad$ Argilloterapia - leczenie wysuszoną i wyprażoną gliną. Stosuje się ją w formie okładów lub podaje w małych ilościach do jedzenia. Zwolennicy tej metody twierdzą, że skutecznie leczy między innymi schorzenia wątroby, nerek, pęcherza, układu kostno-stawowego, stany zapalne skóry, gruźlicę, skutki przeziębień, choroby serca i migrenę.

- Akupunktura - chińska metoda leczenia polegająca na nakłuwaniu odpowiednich punktów ciała. Stosowana głównie w leczeniu bólu.

- $\quad$ Akupresura - masaż punktowy, polegający na uciskaniu, dotykaniu, głaskaniu i opukiwaniu określonych miejsc na ciele ludzkim, które odpowiadają poszczególnym organom [4].

- $\quad$ Apiterapia - leczenie produktami pszczelimi [5].

- $\quad$ Aromaterapia - terapia zapachami, czyli terapia z wykorzystaniem olejków eterycznych i innych substancji zapachowych.

- Bajkoterapia - polega na czytaniu bajek terapeutycznych, które mają pozytywnego bohatera, dobre zakończenie.

- Bioenergoterapia - wykorzystuje zdolności energetyczne bioenergoterapeuty. Wynika ona z przekonania, że każdego człowieka otacza pole bioenergetyczne, czyli aura, w której są widoczne wszystkie choroby.

- Homeopatia - leczenie podobnego podobnym przy użyciu preparatów pochodzenia roślinnego, zwierzęcego (jad) czy mineralnego (siarka, złoto) w bardzo dużym rozcieńczeniu.

- Irydologia - zajmuje się zmianami w tęczówce oka, według irydologów tęczówka oka ma połączenie nerwowe z innymi częściami ciała i reaguje zmianą wyglądu na stany chorobowe danego narządu.

- Koloroterapia - metoda polega na leczeniu kolorami przy wykorzystaniu lamp emitujących białe światło.

- Kręgarstwo - polega na manualnym „naprawianiu" różnego rodzaju zwichnięć kości, stawów, więzadeł, kręgosłupa.

- Masaż - jeden z najstarszych zabiegów medycznych stosowany nie tylko w stanach chorobowych [6].
- $\quad$ Urynoterapia - jedna z najbardziej kontrowersyjnych metod leczenia, która polega na piciu porannego moczu.

- Ziołolecznictwo - fitoterapia, czyli leczenie preparatami roślinnymi.

- Świecowanie uszu - tzw. świece Hopi palą się w uszach około $15 \mathrm{~min}$. Są wykonane z włókna Inianego nasyconego woskiem i ziołami.

- Okłady - stosuje się je podczas urazów i kontuzji [7].

- Terapia próżniowa - zabieg leczniczy z wykorzystaniem baniek [8].

- $\quad$ Muzykoterapia - polega na wykorzystaniu muzyki lub jej elementów (dźwięk, rytm, melodia i harmonia) przez muzykoterapeutę i pacjenta [9].

Analiza literatury przedmiotu wykazała, że rzetelnych i aktualnych źródeł w omawianym zakresie jest niewiele. Tak więc wyniki badań własnych mogą wzbogacić źródła bibliograficzne w tym obszarze.

Badania własne pozwoliły na zestawienie stosowanych działań niefarmakologicznych w najczęstszych problemach zdrowotnych u dzieci, takich jak: biegunka, przeziębienie, gorączka i oparzenia. Zestawienie podejmowanego przez badanych postępowania w wymienionych stanach chorobowych wykazało, że w przypadku biegunki działania w obydwu grupach były prawidłowe. W I grupie badani stosowali przede wszystkim dietę (93\%), a w II grupie nawadnianie (83\%). W przypadku postępowania podczas przeziębienia i gorączki badani w obydwu grupach wymieniali podobne czynności, czyli w przeziębieniu stosowanie preparatów ziołowych (68\% vs $71 \%$ ), a w celu obniżenia temperatury ciała - zimne okłady i kąpiele (95\% vs $79 \%$ ). W przypadku oparzeń w I grupie badani najczęściej stosowali środki domowe, tj.: aloes, jogurt, ogórek, ziemniak (76\%). W II grupie uczestnicy badania najchętniej stosowali zimną wodę i okłady (62\%).

W badaniach własnych w postępowaniu wobec dziecka przeziębionego dominowało podawanie preparatów roślinnych ziołowych, na co w swojej pracy wskazuje także Timmer A. i wsp. [10]. W swoich badaniach zespół ten wykazał, że wyciąg z pelargonii afrykańskiej może złagodzić kaszel oraz produkcję plwociny u dzieci z przeziębieniem. Również może być skuteczny w łagodzeniu objawów ostrego zapalenia oskrzeli u dorosłych i dzieci oraz zapalenia zatok u dorosłych.

Kolejnym analizowanym w badaniach własnych elementem było postępowanie opiekunów w stosunku do dziecka z gorączką. W badaniach własnych respondenci najczęściej wymieniali stosowanie herbatek ziołowych oraz zimne okłady i kąpiele oraz dostosowanie temperatury otoczenia, Iżejszą odzież i chłodne napoje. Podobne metody przedstawia Łoś-Rycharska E. i wsp. 
[11]. W badaniach tego zespołu $88,87 \%$ stosowało niefarmakologiczne metody obniżania temperatury ciała u dzieci z gorączką. Najczęściej owijki 88,61\% i zimne kąpiele $31,01 \%$, zakładanie dziecku lżejszego ubrania, podawanie zimnych napojów oraz wietrzenie pomieszczenia.

Miejscowe leczenie oparzeń jest przedmiotem wielu badań klinicznych. Rany po oparzeniu goją się najlepiej w wilgotnym, jednak nie mokrym otoczeniu, które sprzyja ponownemu naskórkowaniu i zapobiega odwodnieniu komórkowemu. Takie środowisko najlepiej stworzyć nakładając lek działający miejscowo lub opatrunek okluzyjny, aby zmniejszyć utratę płynów. Preparaty sosowane miejscowo zapewniają kontrolę bólu, sprzyjają gojeniu się rany oraz zapobiegają jej zakażeniu i wysuszeniu. Oparzenia powierzchowne można z powodzeniem leczyć, stosując miejscowo lotion, miód, aloes zwykły lub maść antybiotykową. Składnik lipidowy tych środków przyspiesza proces naprawczy uszkodzonej skóry i redukuje jej wysuszenie. Takie wnioski sformułowała Maenthaisong R i wsp. [12] oraz wykazała, że chociaż pacjenci z oparzeniami powierzchownymi nie wymagają żadnych leków, to na podstawie potwierdzonych danych stwierdzono, że miejscowe niesteroidowe środki przeciwzapalne i aloes łagodzą ból. W badaniach własnych badani najczęściej stosowali zimne okłady i z różnych części roślin leczniczych, w tym aloesu [12, 13].

Medycyna niekonwencjonalna może być określona jako zbiór metod leczniczych, które nawiązują do tradycji kulturowych oraz społecznych, przeświadczeń i praktyk, które nie są poparte dowodami z badań naukowych, ale służą poprawie zdrowia, profilaktyce różnych chorób oraz ich leczeniu. Ten rodzaj medycyny nazywany jest często medycyną niekonwencjonalną, tradycyjną, naturalną, alternatywną, holistyczną, komplementarną czy ludową [14].

\section{Wnioski}

1. W dwóch badanych grupach (,przedszkolnej” i „szpitalnej”) ok. 80\% osób stosuje wobec chorych dzieci niefarmakologiczne metody postępowania.

2. Najczęściej rodzice/opiekunowie stosują preparaty ziołowe i czynniki fizykalne.

3. W obu badanych grupach podejmowane działania niefarmakologiczne wobec chorych dzieci były podobne.

4. Jako źródło informacji w badanym zakresie opiekunowie wskazywali Internet i znajomych.

5. Analiza literatury przedmiotu wykazała, że rzetelnych i aktualnych źródeł w omawianym zakresie jest niewiele.

\section{Piśmiennictwo}

1. Górska B. Zioła w tradycji ludowej Podlasia. Część 1. Ciechanowiecki Rocznik Muzealny, tom I, 2006. Dostępne: http://www.ciechanowiec.pl/readarticle.php? article_id=19. Pobrane 7.05.2019 r.

2. Lesińska-Sawicka M, Waśkow M. Medycyna ludowa, gusła i zabobony jako metody lecznicze praktykowane w XXI wieku. Med Rodz. 2012; 1: 10-14.

3. Bąk J. Medycyna alternatywna w Polsce i na świecie. Bielsko-Biała: Dragon; 2017.

4. Skopowska A. Terapie alternatywne. Szerokie zastosowanie wybranych metod z zakresu medycyny wschodniej. Rehabil Prakt. 2018; (3): 54-57.

5. Jagiełło J, Kołeczek E, Horochowska M, Zdrojewicz Z, Głowaczewska A. Bursztynowe źródło zdrowia - zastosowanie miodu we współczesnej medycynie. Med Rodz. 2018; 21(1): 64-69.

6. Borgosz-Guźda A. Wpływ masażu na rozwój psychofizyczny niemowląt - siła dotyku. W: Zeszyty PedagogicznoMedyczne. Żmichrowska JM. (red). Wałbrzych: WWSZiP; 2017; T. 44(5): 257-261.

7. Lange P. Red. Domowe sposoby leczenia dzieci. Warszawa: Vocatio; 1999, wyd. III.

8. Andriyuk L, Batkiewicz W. Vacuterapia - terapia próżniowa. Rehabil Prakt. 2016; 6: 62-67.

9. Paszkiewicz-Mes E. Muzykoterapia jako metoda wspomagająca leczenie. Hygeia Public Health. 2013; 48(2): 168-176.

10. Timmer A, Günther J, Rücker G, Motschall E, Antes G, Kern WV. Pelargonium sides extract for acute respiratory tract infections. Cochrane Database Syst Rev. 2008; 3: CD006323.

11. Łoś-Rycharska E, Sterkowicz A, Czerwionka-Szaflarska M. Fizyczne metody obniżania temperatury ciała u dzieci gorączkujących - analiza postępowania rodziców na podstawie badań ankietowych. Ped Pol. 2016; 91: 122-127.

12. Maenthaisong R, Chaiyakunapruk N, Niruntraporn S, Kongkaew $C$. The efficacy of aloe vera used for burn wound healing: a systematic review. Burns 2007; 33(6): 713-718.

13. https://www.mp.pl/medycynarodzinna/artykuly/121031, oparzenia-leczone-pozaszpitalnie-zapobieganie-i-opieka

14. Wysocka G, Krajewska-Kułak E, Gryko K, Fiłon J. Poglądy studentów kierunku pielęgniarstwo na temat medycyny niekonwencjonalnej - doniesienie wstępne. Piel Zdr Publ. 2015; 5(1): 41-51.

Artykuł przyjęty do redakcji: 21.02.2021.

Artykuł przyjęty do publikacji: 23.08.2021.

Źródło finansowania: Praca finansowana w ramach umowy statutowej SUM nr KNW-1-096/N/9/Z

Konflikt interesów: Autorzy deklarują brak konfliktu interesów.

\author{
Adres do korespondencji: \\ Beata Jarecka \\ ul. Batorego 15 \\ 41-902 Bytom \\ e-mail bjarecka@sum.edu.pl \\ Oddział Kliniczny Pediatrii Katedry Pediatrii, Wydział Nauk o Zdro- \\ wiu w Katowicach, Śląski Uniwersytet Medyczny w Katowicach
}

